\title{
Rapid and Simultaneous Analysis of Seven Oral Anti-Diabetic Drugs
}

\author{
Ayham Al Ansari $^{a}$, M. Jamal Al Khatib ${ }^{b}$ and Fatema Al Rahal ${ }^{c}$ \\ ${ }^{a}$ Department of Chemistry, Faculty of Science, University of Damascus, Damascus, Syria. \\ ${ }^{b}$ Department of Chemistry, Faculty of Science, University of Damascus, Damascus, Syria. \\ ${ }^{c}$ Department of Chemistry, Faculty of Science, University of Al Baath, Homs, Syria.
}

Received: $26^{\text {th }}$ June 2020;

Accepted: $15^{\text {th }}$ Dec. 2020

\begin{abstract}
The present study describes the optimization and validation of a highperformance liquid chromatographic (HPLC) method for the determination of seven medicines (Metformin hydrochloride, Vildagliptin, Gliclazide, Sitagliptin phosphate, Pioglitazone hydrochloride, Glibenclamide and Glimepirde) in bulk and pharmaceutical dosage forms. The chromatographic separation could be achieved using a C8 column (100 $\AA, 5 \mu \mathrm{m}, 150 \mathrm{~mm})$ at $30{ }^{\circ} \mathrm{C}$. Thereby, the mobile phase is a mixture of acetonitrile and an aqueous solution of triethylamine $(0.5 \% \mathrm{v} / \mathrm{v})$ and phosphoric acid $10 \% \mathrm{w} / \mathrm{v}(\mathrm{pH} 7.0)$ at a mixing ratio of 32.5:67.5 v/v\%, with a flow rate of $1.0 \mathrm{ml} / \mathrm{min}$ and detection performed at $210 \mathrm{~nm}$ using a UV detector. The results were found satisfactory and the method can be adapted to routine quality control of medications as recommended by the guidelines of the International Conference on Harmonization.
\end{abstract}

Keywords: Metformin hydrochloride, Vildagliptin, Gliclazide, Sitagliptin phosphate, Pioglitazone hydrochloride, Glibenclamide, Glimepirde, Reversed phase, HPLC, Pharmaceutical dosage forms.

\section{Introduction}

Diabetes mellitus, commonly known as diabetes, is a metabolic disease that causes high blood sugar. The hormone insulin allows sugar in blood stream to enter the cells where it is stored or used for energy. With diabetes, the body either doesn't make enough insulin or can't effectively use the insulin it does make, resulting in high blood sugar which, if untreated, can damage the nerves, eyes, kidneys and other organs ${ }^{[1]}$. In the following, common diabetes medications are briefly described.

Metformin hydrochloride (MET), N,N-dimethylimidocarbonimidic diamide hydrochloride $(1: 1)$, is a bigua-nide oral antihyperglycemic drug used in the management of type-2 diabetes $^{[2]}$. Vildagliptin (VLD), ((S)-1-\{2-(3hydroxy-adamantan-1-yl-amino)acetyl]pyrrolidine-2-carbonitrile, is an anti-diabetic drug that belongs to the dipeptidyl peptidase-4 (DPP-4) inhibitor class. It reduces the glucose-induced glucagon-like peptide 1 as well as the gastric inhibitory polypeptide secretion. It is used as a monotherapy in adults with type 2 diabetes mellitus, especially in patients inadequately controlled by diet and exercise alone ${ }^{[3,4]}$. Gliclazide (GLZ), (1-(3-azabicyclo[3.3.0]-oct-3yl)-3-ptolylsulfonylurea, is a sulphonyl urea derivative which acts by increasing the sensitivity of the beta cells of islets of Langerhans $^{[5]}$. Sitagliptin phosphate (STG), 7[(3R)-3-amino-1-oxo-4-(2,4,5-trifluro-phenyl]5,6,7,8-tet-rahydro-3-(trifluromethyl)-1, 2,4-triazole[4,3]py-razoline phosphate monohydrate, is a new oral antidiabetic agent that blocks the dipeptidyl peptidase-4 (DPP-4) activity thus, increasing the incretin levels (GLP-1 and GIP), which inhibits glucagon release ${ }^{[6]}$. Pioglitazone hydrochloride (PGZ), (R,S)-5-(4-[2-(5-ethylpyridin-2-yl)ethoxy]benzyl)thia-zolidine-2,4-dione, is a thiazolidine-dione oral antidiabetic 
similar to rosiglitazone. It is given orally as a monotherapy, particularly in patients who are overweight and for whom metformin is contraindicated or not tolerated ${ }^{[7]}$. Glibenclamide (GLB), 1-[4-[2-(chloro-2-methoxybenzamido)ethyl]-benzenesulphonyl]-3-cyclohexylurea, is an oral hypoglycemic agent of the sulphonylurea class widely used in the treatment of type II diabetes mellitus. It lowers blood glucose concentration by stimulating the release of insulin from the pancreatic beta cells ${ }^{[8,9]}$. Glimepiride (GLM), 3-ethyl-4-methyl-N-(4-[N((1r,4r)-4-methylcyclohexyl-carbamoyl)sulfamoyl]phenethyl)-2-oxo-2,5-dihydro-1H-pyrrole1-carboxamide, is an oral hypoglycemic agent that acts by stimulating the release of insulin from functioning pancreatic beta cells and increasing the sensitivity of peripheral tissues to insulin $^{[10-12]}$.

Several methods have been developed for the simultaneous determination of anti-diabetic drugs, including spectrophotometry, HPLC and voltammetry (Table 1). The objective of this work is to develop and validate a rapid, sensitive, accurate and precise HPLC method to simultaneously quantify the seven anti-diabetic drugs mentioned above in pharmaceutical dosage form, which could be applied in a routine drug quality control.

Table 1: Data of anti-diabetic drugs.

\begin{tabular}{|c|c|c|c|c|}
\hline Name & $\begin{array}{l}\text { Chemical } \\
\text { Formula }\end{array}$ & $\begin{array}{c}\text { Molecular } \\
\text { Weight }\end{array}$ & Method of Analysis & Ref. \\
\hline \multirow{4}{*}{$\begin{array}{c}\text { Metformin } \\
\text { hydrochloride }\end{array}$} & \multirow{4}{*}{$\mathrm{C}_{4} \mathrm{H}_{11} \mathrm{~N}_{5}$} & \multirow{4}{*}{$129.16 \mathrm{~g} \cdot \mathrm{mol}^{-1}$} & Spectrophotometry & $13-15$ \\
\hline & & & HPTLC & 16 \\
\hline & & & HPLC & 17 \\
\hline & & & Voltammetry & $18-20$ \\
\hline \multirow[b]{2}{*}{ Vildagliptin } & \multirow[b]{2}{*}{$\mathrm{C}_{17} \mathrm{H}_{25} \mathrm{~N}_{3} \mathrm{O}_{2}$} & \multirow[b]{2}{*}{$303.40 \mathrm{~g} \cdot \mathrm{mol}^{-1}$} & Spectrophotometry & $21-22$ \\
\hline & & & HPLC & $23-24$ \\
\hline \multirow{3}{*}{ Gliclazide } & \multirow{3}{*}{$\mathrm{C}_{15} \mathrm{H}_{21} \mathrm{~N}_{3} \mathrm{O}_{3} \mathrm{~S}$} & \multirow{3}{*}{$323.41 \mathrm{~g} \cdot \mathrm{mol}^{-1}$} & Spectrophotometry & $25-26$ \\
\hline & & & TLC & 27 \\
\hline & & & HPLC & 28 \\
\hline \multirow{4}{*}{$\begin{array}{l}\text { Sitagliptin } \\
\text { phosphate }\end{array}$} & \multirow{4}{*}{$\mathrm{C}_{16} \mathrm{H}_{16} \mathrm{ClF}_{6} \mathrm{~N}_{5} \mathrm{O}$} & \multirow{4}{*}{$523.32 \mathrm{~g} \cdot \mathrm{mol}^{-1}$} & Spectrophotometry & $29-30$ \\
\hline & & & TLC & 31 \\
\hline & & & HPLC & 32 \\
\hline & & & Voltammetry & 33 \\
\hline \multirow{3}{*}{$\begin{array}{l}\text { Pioglitazone } \\
\text { hydrochloride }\end{array}$} & \multirow{3}{*}{$\mathrm{C}_{19} \mathrm{H}_{21} \mathrm{ClN}_{2} \mathrm{O}_{3} \mathrm{~S}$} & \multirow{3}{*}{$392.90 \mathrm{~g} \cdot \mathrm{mol}^{-1}$} & Spectrophotometry & $34-35$ \\
\hline & & & HPLC & $36-37$ \\
\hline & & & Voltammetry & $38-39$ \\
\hline \multirow{3}{*}{ Glibenclamide } & \multirow{3}{*}{$\mathrm{C}_{23} \mathrm{H}_{28} \mathrm{ClN}_{3} \mathrm{O}_{5} \mathrm{~S}$} & \multirow{3}{*}{$494.00 \mathrm{~g} \cdot \mathrm{mol}^{-1}$} & Spectrophotometry & $40-41$ \\
\hline & & & HPLC & $42-43$ \\
\hline & & & Voltammetry & 44 \\
\hline \multirow{3}{*}{ Glimepiride } & \multirow{3}{*}{$\mathrm{C}_{24} \mathrm{H}_{34} \mathrm{~N}_{4} \mathrm{O}_{5} \mathrm{~S}$} & \multirow{3}{*}{$490.617 \mathrm{~g} \cdot \mathrm{mol}^{-1}$} & Spectrophotometry & $45-46$ \\
\hline & & & TLC & 47 \\
\hline & & & HPLC & 48 \\
\hline
\end{tabular}

\section{Materials and Methods}

\section{Materials}

The working standards of the seven drugs were purchased as indicated below: Metformin hydrochloride (potency 99.95\%) from Smruthi Organics, India; Vildagliptin (potency $99.94 \%$ ) from Lee Pharma Limited, India; Sitagliptin phosphate monohydrate (potency 99.97\%) from Morepen, India; Pioglitazone hydrochloride (potency 99.94\%) from Smilax Laboratories,
Limited, India; Gliclazide (potency 99.91\%) from Shandong Keyuan Pharmaceutical, China, Glimepirde (potency 99.96\%) and Glibenclamide (potency 99.95\%) from Elixir Pharma, India. Triethyl-amine, phosphoric acid and acetonitrile of HPLC grade were purchased from Chem Lab (Belgium). Standard stock solutions $(1000 \mu \mathrm{g} / \mathrm{ml})$ were then prepared under sonication using the mobile phase as a solvent. One liter of the mobile phase consists thereby of 325 $\mathrm{ml}$ acetonitrile and $625 \mathrm{ml}$ of aqueous buffer 
solution containing $5.0 \mathrm{ml}$ triethylamine and adjusted by phosphoric acid at $\mathrm{pH}=7.0$. The prepared stock solutions were stored at $4{ }^{\circ} \mathrm{C}$ and protected from light. Calibration standards were prepared by diluting the standard stock solution in the mobile phase.

To prepare the sample solutions, the mean weight of powdered tablets was accurately transferred into a $100-\mathrm{mL}$ calibrated volumetric flask; mobile phase was added. Extraction was carried out for $15 \mathrm{~min}$ in an ultrasonic bath at room temperature, then diluted with the mobile phase to the mark. The solutions were filtered through a $0.45-\mu \mathrm{m}$ filter. Then, the solutions were diluted with the mobile phase depending on the drug concentration required. All preparations were performed in five replicates.

\section{Analysis}

Quantitative HPLC was performed on a lowpressure gradient LC-2010CHT SHIMADZU High-Pressure Liquid Chromatograph (Japan). The instrument is provided with solvent delivery module and with a PDA detector SHIMADZU phenomix. An auto injector and window-based
CLASS VP software were used for automatic operation, recording and analysis.

The analysis was carried out with an injection volume of $20 \mu \mathrm{l}$ at a flow rate of $1.0 \mathrm{ml} / \mathrm{min}$. The detection wavelength was $210 \mathrm{~nm}$ and the total analysis time was 10 minutes. Separation was achieved on a Thermo C8-column (100 $\AA, 5 \mu \mathrm{m}$, $4.6 \times 150 \mathrm{~mm}$ ) at $30{ }^{\circ} \mathrm{C}$. The mobile phase was degassed and filtered through a $0.45-\mu \mathrm{m}$ filter paper prior to use.

From the calibration plots, it was found that the response to the anti-diabetic drugs was a linear function of concentration in the range $0.05-100.00 \mu \mathrm{g} / \mathrm{ml}$ for MET, $0.25-100.00 \mu \mathrm{g} / \mathrm{ml}$ for VLD and STG, respectively and 0.10-100.00 $\mu \mathrm{g} / \mathrm{ml}$ for GLZ, PGZ, GLB and GLM, respectively.

\section{Results and Discussion}

Figure 1 represents an example of the chromatograms obtained by the optimized method, which was validated in terms of linearity and range, limit of detection, limit of quantification, precision, accuracy, selectivity and specificity, robustness and system suitability, as per ICH guidelines $^{[49,50]}$.

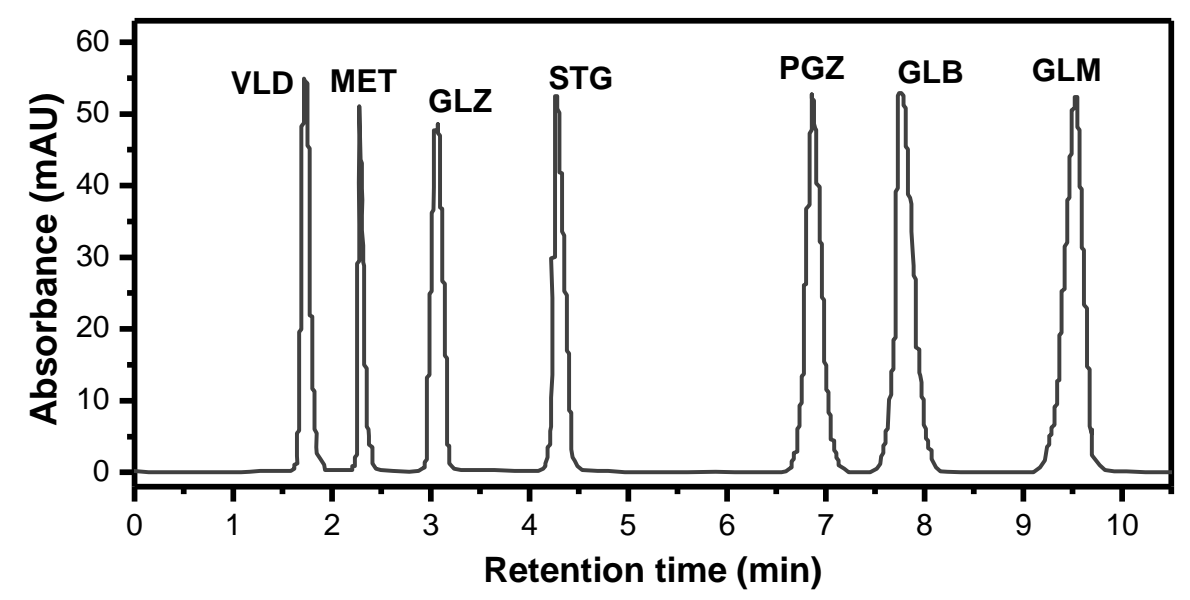

Figure 1. Typical chromatogram for MET, VLD, GLZ, STG, PGZ, GLB and GLM with concentrations of 5.0, 20.0, 8.0, 19.0, $8,7.5$ and $16.0 \mu \mathrm{g} / \mathrm{ml}$, respectively.

Linearity was assessed with the aid of serially diluted calibration solutions as mentioned above. The standards were injected separately. Calibration curves were constructed by plotting average peak areas against concentration and regression equation was computed. The results are presented in Table 2 which shows that an excellent correlation exists between the peak area and concentration in the specified range. The limit of detection (LOD) and limit of quantitation (LOQ) for the procedure were performed on samples containing very low concentrations of analytes under the ICH guidelines ${ }^{[51]}$. Based on the standard deviation of the response and the slope, the LOD and LOQ were determined. LOD and LOQ were calculated using the equations LOD = $3.3 \mathrm{SD} / m$ and $\mathrm{LOQ}=10 \mathrm{SD} / m$, where $\mathrm{SD}$ is the standard deviation of the blank and $m$ is the slope of the calibration curve. The results are reported in Table 2. 
Table 2: Regression characteristics of the proposed HPLC method.

\begin{tabular}{lccccc}
\hline & Linear range & Regression equation & $\mathbf{R}^{\mathbf{2}}$ & LOD $\boldsymbol{\mu g} / \mathbf{m l}$ & LOQ $\mathbf{g} / \mathbf{m l}$ \\
\cline { 2 - 6 } MET & $0.05-100.00$ & Area $=71630 \mathrm{C}+10310$ & 0.9998 & 0.011 & 0.033 \\
VLD & $0.25-100.00$ & Area $=16650 \mathrm{C}-2220$ & 0.9992 & 0.064 & 0.194 \\
GLZ & $0.10-100.00$ & Area $=48690 \mathrm{C}+780$ & 1.0000 & 0.033 & 0.100 \\
STG & $0.25-100.00$ & Area $=26930 \mathrm{C}+8540$ & 0.9996 & 0.081 & 0.245 \\
PGZ & $0.10-100.00$ & Area $=82600 \mathrm{C}+5220$ & 0.9999 & 0.032 & 0.097 \\
GLB & $0.10-100.00$ & Area $=102636 \mathrm{C}+29217$ & 0.9998 & 0.041 & 0.124 \\
GLM & $0.10-100.00$ & Area $=58250 \mathrm{C}+9640$ & 0.9999 & 0.035 & 0.106 \\
\hline
\end{tabular}

$95 \%$ confidence level.

Accuracy and precision were identified with standard quality control samples that were prepared at different concentration levels covering the linear field range. The repeatability and reproducibility are reported as RSD\% in Table 3; minimum variation in the \%RSD indicates that the present method is precise. Accuracy was determined by applying the described method to synthetic mixtures of excipients (lactose anhydrous, mannitol, corn starch, crospovidone, microcrystalline cellulose, magnesium stearate, silicon dioxide and titanium dioxide) to which known amounts of each drug at the level described in the table were added and analyzed by the proposed method. The accuracy was then calculated as the percentage of each drug recovered by the assay (Table 4 ). The recovery values of the drugs from the tablet dosage forms by the developed method range from 98.80 to $102.3 \%$ (Table 4). This good recovery values indicate that the proposed method is highly accurate.

No peak interference of blank and placebo at the retention time of MET, VLD, GLZ, STG, PGZ, GLB and GLM was observed. This indicates that the method is specific for the analytes in their pharmaceutical dosage form. The specificity of the method is illustrated in Figure 1, where complete separation of MET, VLD, GLZ, STG, PGZ, GLB and GLM was noticed. The average retention time $\left(t_{R} \pm S D\right)$ for MET, VLD, GLZ, STG, PGZ, GLB and GLM was found to be $1.727 \pm 0.01,2.304 \pm 0.02$, $3.046 \pm 0.03,4.272 \pm 0.02,6.866 \pm 0.02,7.784 \pm$ 0.01 and $9.438 \pm 0.03 \mathrm{~min}$, respectively, for five replicates.

Method specificity was assessed by studying the chromatograms obtained for a mixture of combined drugs and excipients. The method was found to be specific since no excipients were involved in the analysis. Hence, it was found that the method is suitable for analyzing commercial anti-diabetic formulations.

Predetermined variations were performed under the experimental conditions of the RPHPLC method to assess its robustness. The variations imposed on the chromatographic method are summarized in Table 5. The modifications include different mobile phases, different $\mathrm{pH}$ values of buffer solution, flow rates and wavelengths of detection and different column temperatures (Table 5).

System suitability parameters were studied with five replicates of standard sample solutions; the parameters are presented in Table 6.

\section{Application of the Method to Pharmaceutical Formulations}

Before the assay of the formulations, five replicates of the required dilutions were prepared from the stock solution and sonicated for $10 \mathrm{~min}$. The solutions $(20 \mu \mathrm{l})$ were then injected for quantitative analysis. The amounts of antidiabetic drug per tablet were calculated by extrapolating the peak area from the calibration curve. The results are reported in Table 7.

The statistical Student's t-test and F-test were applied to compare the accuracy and precision of the proposed methods with the accuracy and precision of the official methods. The results are summarized in Table 7. From the results, it is apparent that the calculated t-value and F-value at $95 \%$ confidence level did not exceed the tabulated values of 2.776 and 6.26, respectively, for 5 degrees of freedom. The results indicated that there is no significant variation between the proposed methods and the reference method with respect to accuracy and precision. 
Table 3: Precision and accuracy of the analytical results $(n=5)$.

\begin{tabular}{|c|c|c|c|c|c|c|c|}
\hline \multicolumn{8}{|c|}{ Intra-day } \\
\hline & \multicolumn{2}{|c|}{$\mu \mathrm{g} / \mathrm{ml}$} & \multirow[b]{2}{*}{ SD* } & \multirow{2}{*}{ RSD\% } & \multirow{2}{*}{ Recovery\% } & \multirow{2}{*}{ ASE } & \multirow{2}{*}{$\bar{X} \pm \mathbf{C L}$} \\
\hline & $\mathbf{C}_{\text {THEORY }}$ & $\mathrm{C}_{\text {FOUND }}$ & & & & & \\
\hline \multirow{4}{*}{ MET } & 5.00 & 4.97 & 0.08 & 1.61 & 99.40 & 0.04 & $4.97 \pm 0.10$ \\
\hline & 10.00 & 10.01 & 0.13 & 1.30 & 100.10 & 0.06 & $10.01 \pm 0.16$ \\
\hline & 25.00 & 24.95 & 0.17 & 0.68 & 99.80 & 0.08 & $24.95 \pm 0.21$ \\
\hline & 5.00 & 5.02 & 0.09 & 1.79 & 100.44 & 0.04 & $5.02 \pm 0.11$ \\
\hline \multirow[t]{3}{*}{ VLD } & 10.00 & 10.01 & 0.08 & 0.80 & 100.10 & 0.04 & $10.01 \pm 0.10$ \\
\hline & 25.00 & 25.12 & 0.18 & 0.72 & 100.48 & 0.08 & $25.12 \pm 0.22$ \\
\hline & 5.00 & 5.05 & 0.08 & 1.58 & 101.00 & 0.04 & $5.05 \pm 0.10$ \\
\hline \multirow[t]{3}{*}{ GLZ } & 10.00 & 10.07 & 0.16 & 1.59 & 100.70 & 0.07 & $10.07 \pm 0.20$ \\
\hline & 25.00 & 25.02 & 0.06 & 0.24 & 100.08 & 0.03 & $25.02 \pm 0.07$ \\
\hline & 5.00 & 4.99 & 0.09 & 1.80 & 99.80 & 0.04 & $4.99 \pm 0.11$ \\
\hline \multirow[t]{3}{*}{ STG } & 10.00 & 10.07 & 0.13 & 1.29 & 100.70 & 0.06 & $10.07 \pm 0.16$ \\
\hline & 25.00 & 24.99 & 0.09 & 0.36 & 99.96 & 0.04 & $24.99 \pm 0.11$ \\
\hline & 5.00 & 5.05 & 0.09 & 1.78 & 101.00 & 0.04 & $5.05 \pm 0.11$ \\
\hline \multirow[t]{3}{*}{ PGZ } & 10.00 & 10.03 & 0.11 & 1.10 & 100.30 & 0.05 & $10.03 \pm 0.14$ \\
\hline & 25.00 & 25.01 & 0.10 & 0.40 & 100.04 & 0.04 & $25.01 \pm 0.12$ \\
\hline & 5.00 & 5.02 & 0.09 & 1.79 & 100.40 & 0.04 & $5.02 \pm 0.11$ \\
\hline \multirow[t]{3}{*}{ GLB } & 10.00 & 9.99 & 0.11 & 1.10 & 99.90 & 0.05 & $9.99 \pm 0.14$ \\
\hline & 25.00 & 24.96 & 0.21 & 0.84 & 99.84 & 0.09 & $24.96 \pm 0.26$ \\
\hline & 5.00 & 5.02 & 0.07 & 1.39 & 100.40 & 0.03 & $5.02 \pm 0.09$ \\
\hline \multirow[t]{2}{*}{ GLM } & 10.00 & 10.08 & 0.17 & 1.69 & 100.80 & 0.08 & $10.08 \pm 0.21$ \\
\hline & 25.00 & 25.02 & 0.34 & 1.36 & 100.08 & 0.15 & $25.02 \pm 0.42$ \\
\hline \multicolumn{8}{|c|}{ Inter-day } \\
\hline & \multicolumn{2}{|c|}{$\mu \mathrm{g} / \mathrm{ml}$} & & RSD\% & Recovery \% & $\mathbf{S E}$ & $\overline{\boldsymbol{X}}+\boldsymbol{C I}$ \\
\hline & $\mathbf{C}_{\text {THEORY }}$ & C FOUND $_{\text {F }}$ & SD* & RSD\% & Recovery \% & ASE & $x \pm$ CL \\
\hline \multirow{3}{*}{ MET } & 5.00 & 4.96 & 0.07 & 1.41 & 99.20 & 0.03 & $4.96 \pm 0.09$ \\
\hline & 10.00 & 10.02 & 0.14 & 1.40 & 100.20 & 0.06 & $10.02 \pm 0.17$ \\
\hline & 25.00 & 24.93 & 0.19 & 0.76 & 99.72 & 0.08 & $24.93 \pm 0.24$ \\
\hline \multirow{3}{*}{ VLD } & 5.00 & $5.01^{\prime}$ & 0.08 & 1.60 & 100.20 & 0.04 & $5.01 \pm 0.10$ \\
\hline & 10.00 & 10.05 & 0.07 & 0.70 & 100.50 & 0.03 & $10.05 \pm 0.09$ \\
\hline & 25.00 & 25.10 & 0.15 & 0.60 & 100.40 & 0.07 & $25.10 \pm 0.19$ \\
\hline \multirow{3}{*}{ GLZ } & 5.00 & 5.04 & 0.07 & 1.39 & 100.80 & 0.03 & $5.04 \pm 0.09$ \\
\hline & 10.00 & 10.02 & 0.12 & 1.20 & 100.20 & 0.05 & $10.02 \pm 0.15$ \\
\hline & 25.00 & 25.06 & 0.09 & 0.36 & 100.24 & 0.04 & $25.06 \pm 0.11$ \\
\hline \multirow{3}{*}{ STG } & 5.00 & 5.03 & 0.08 & 1.59 & 100.60 & 0.04 & $5.03 \pm 0.10$ \\
\hline & 10.00 & 10.05 & 0.15 & 1.49 & 100.50 & 0.07 & $10.05 \pm 0.19$ \\
\hline & 25.00 & 25.03 & 0.11 & 0.44 & 100.12 & 0.05 & $25.03 \pm 0.14$ \\
\hline \multirow{3}{*}{ PGZ } & 5.00 & 5.07 & 0.08 & 1.58 & 101.40 & 0.04 & $5.07 \pm 0.10$ \\
\hline & 10.00 & 10.07 & 0.10 & 0.99 & 100.70 & 0.04 & $10.07 \pm 0.12$ \\
\hline & 25.00 & 25.04 & 0.13 & 0.52 & 100.16 & 0.06 & $25.04 \pm 0.16$ \\
\hline & 5.00 & 4.99 & 0.08 & 1.60 & 99.80 & 0.04 & $4.99 \pm 0.10$ \\
\hline GLB & 10.00 & 9.98 & 0.11 & 1.10 & 99.80 & 0.05 & $9.98 \pm 0.14$ \\
\hline & 25.00 & 24.97 & 0.20 & 0.80 & 99.88 & 0.09 & $24.97 \pm 0.25$ \\
\hline & 5.00 & 4.98 & 0.05 & 1.00 & 99.60 & 0.02 & $4.98 \pm 0.06$ \\
\hline GLM & 10.00 & 10.02 & 0.14 & 1.40 & 100.20 & 0.06 & $10.02 \pm 0.17$ \\
\hline & 25.00 & 24.97 & 0.31 & 1.24 & 99.88 & 0.14 & $24.97 \pm 0.38$ \\
\hline
\end{tabular}

ASE: Analytical Standard Error.

R\%: Recovery.

CL: Confidence Limit. 
Table 4. Recoveries of drugs by the proposed HPLC method.

\begin{tabular}{|c|c|c|c|c|c|c|c|}
\hline \multirow[b]{2}{*}{ Compound } & \multicolumn{3}{|c|}{$(\mu \mathrm{g} / \mathrm{ml})$} & \multirow[b]{2}{*}{$\begin{array}{l}\text { Recovery } \\
\text { mean } \%\end{array}$} & \multirow[b]{2}{*}{ SD } & \multirow[b]{2}{*}{ ASE } & \multirow[b]{2}{*}{ RSD \% } \\
\hline & $\begin{array}{c}\text { Original } \\
\text { mean level }\end{array}$ & $\begin{array}{c}\text { Spiked } \\
\text { level }\end{array}$ & $\begin{array}{c}\text { Detected } \\
\text { mean level }\end{array}$ & & & & \\
\hline MET & 50.02 & 10.00 & 59.93 & 99.10 & 0.13 & 0.06 & 1.31 \\
\hline VLD & 25.03 & 10.00 & 34.98 & 99.50 & 0.11 & 0.05 & 1.11 \\
\hline GLZ & 29.98 & 10.00 & 40.02 & 100.40 & 0.07 & 0.03 & 0.70 \\
\hline STG & 49.96 & 10.00 & 59.94 & 99.80 & 0.09 & 0.04 & 0.90 \\
\hline PGZ & 15.02 & 10.00 & 25.04 & 100.20 & 0.13 & 0.06 & 1.30 \\
\hline GLB & 5.03 & 10.00 & 14.91 & 98.80 & 0.17 & 0.08 & 1.72 \\
\hline GLM & 1.98 & 10.00 & 12.21 & 102.30 & 0.19 & 0.08 & 1.86 \\
\hline
\end{tabular}

Table 5: Robustness of the method.

\begin{tabular}{|c|c|c|c|}
\hline Condition & Variation & Observation & Result \\
\hline \multirow{3}{*}{$\begin{array}{l}\text { Volume of } \\
\text { acetonitrile } \%\end{array}$} & $40 \%, 35 \%$ & Poor peak shape and poor separation for most analytes. & Rejected \\
\hline & $32.5 \%$ & $\begin{array}{l}\text { Good peak shape for all analytes and all seven analytes were } \\
\text { completely separated from matrix component. }\end{array}$ & Accepted \\
\hline & $30 \%, 25 \%$ & $\begin{array}{l}\text { Low sensitivity for most analytes, retention too long (more } \\
\text { than } 30 \text { minutes). }\end{array}$ & Rejected \\
\hline \multirow{3}{*}{$\begin{array}{l}\mathrm{pH} \text { of buffer } \\
\text { solution }\end{array}$} & 6 & $\begin{array}{l}\text { Poor separation for MET, VLD and retention too long for } \\
\text { other separated substances. }\end{array}$ & Rejected \\
\hline & 7 & $\begin{array}{l}\text { Good peak shape for all seven analytes; all seven analytes } \\
\text { were completely separated from matrix component. }\end{array}$ & Accepted \\
\hline & 8 & $\begin{array}{l}\text { Poor separation of materials with overlapping of the peaks; } \\
\text { four peaks appeared and the analysis time did not exceed } \\
\text { seven minutes. }\end{array}$ & Rejected \\
\hline \multirow{3}{*}{$\begin{array}{l}\text { Flow rate } \\
\mathrm{ml} / \mathrm{min}\end{array}$} & 0.8 & Retention too long for the method (more than 15 minutes). & Rejected \\
\hline & 1 & $\begin{array}{l}\text { Good peak shape for all seven analytes and all seven analytes } \\
\text { were completely separated from matrix component. }\end{array}$ & Accepted \\
\hline & $1.2,1.4$ & $\begin{array}{l}\text { Poor separation for MET, VLD and low resolution between } \\
\text { PGZ and GLB. }\end{array}$ & Rejected \\
\hline \multirow{2}{*}{$\begin{array}{l}\text { Detection } \\
\text { wavelength }\end{array}$} & $210 \mathrm{~nm}$ & $\begin{array}{l}\text { Good peak shape for all seven analytes and all seven analytes } \\
\text { were completely separated from matrix component. }\end{array}$ & Accepted \\
\hline & $\begin{array}{l}\text { More than } \\
210 \mathrm{~nm}\end{array}$ & $\begin{array}{l}\text { Poor separation and low sensitivity of materials with } \\
\text { overlapping of the peaks at high wavelengths. }\end{array}$ & Rejected \\
\hline \multirow{3}{*}{$\begin{array}{l}\text { Temperature } \\
{ }^{\circ} \mathrm{C}\end{array}$} & 20,25 & $\begin{array}{l}\text { Poor separation for MET and VLD and overlap between PGZ } \\
\text { and GLB. }\end{array}$ & Rejected \\
\hline & 30 & $\begin{array}{l}\text { Good peak shape for all seven analytes; all seven analytes were } \\
\text { completely separated from matrix component. }\end{array}$ & Accepted \\
\hline & 35,40 & Overheating does not improve the robustness of the method. & Rejected \\
\hline
\end{tabular}


Table 6: System suitability parameters for MET, VLD, GLZ, STG, PGZ, GLB and GLM by the proposed HPLC method.

\begin{tabular}{|c|c|c|c|c|c|c|c|c|}
\hline Parameters & MET & VLD & GLZ & STG & PGZ & GLB & GLM & Limit Value \\
\hline $\begin{array}{c}\text { RSD\% of } \\
\text { retention time }\end{array}$ & 1.10 & 1.21 & 0.91 & 1.12 & 0.87 & 0.65 & 0.91 & $\mathrm{RSD}<2 \%$ \\
\hline $\begin{array}{l}\text { RSD } \% \text { of peak } \\
\text { area }\end{array}$ & 1.01 & 1.11 & 0.83 & 1.22 & 0.77 & 0.85 & 1.04 & RSD $<2 \%$ \\
\hline $\begin{array}{l}\text { Theoretical } \\
\text { plates }(N)\end{array}$ & 3314 & 3236 & 4482 & 5819 & 7798 & 7606 & 8079 & $N>2000$ \\
\hline $\begin{array}{c}\text { Peak } \\
\text { Asymmetry }(T)\end{array}$ & 1.33 & 1.26 & 1.24 & 1.18 & 1.17 & 1.18 & 1.18 & $\mathrm{~T} \leq 2$ \\
\hline $\begin{array}{c}\text { Capacity } \\
\text { factor }\left(K_{-}\right)\end{array}$ & 1.38 & 2.2 & 3.23 & 4.93 & 8.53 & 9.81 & 12.1 & $1<\mathrm{K}<20$ \\
\hline Selectivity $(\alpha)^{\mathrm{a}}$ & ---- & 1.59 & 1.47 & 1.52 & 1.73 & 1.15 & 1.23 & $\alpha>1$ \\
\hline $\begin{array}{l}\text { Resolution } \\
(\mathbf{R s})^{\mathrm{a}}\end{array}$ & ----- & 3.2 & 3.73 & 2.51 & 7.74 & 2.17 & 3.36 & $\mathrm{Rs} \geq 2$ \\
\hline $\operatorname{HETP}(H)^{b}$ & 0.004 & 0.005 & 0.003 & 0.003 & 0.002 & 0.002 & 0.002 & ---- \\
\hline
\end{tabular}

${ }^{\mathrm{a}}$ With respect to previous peak.

${ }^{\mathrm{b}}$ HETP (height equivalent to theoretical plate).

Table 7: Quantitative determination in pharmaceutical formulations.

\begin{tabular}{|c|c|c|c|c|c|c|c|c|}
\hline \multirow{2}{*}{ Product Name } & \multirow{2}{*}{$\begin{array}{c}\text { Label } \\
\text { amount, mg }\end{array}$} & \multicolumn{3}{|c|}{ Proposed method } & \multicolumn{3}{|c|}{ Reference method } & \multirow{2}{*}{ F-test } \\
\hline & & $\mathbf{R} \%$ & RSD \% & t-test & $\mathbf{R} \%$ & RSD\% & t-test & \\
\hline $\begin{array}{l}{ }^{1} \text { METFORMIN } \\
\text { CITYPHARMA }\end{array}$ & MET 500 & 99.90 & 1.80 & 0.12 & 100.10 & 0.90 & 0.25 & 4.00 \\
\hline${ }^{2}$ METFORAL & MET 850 & 99.60 & 1.20 & 0.74 & 100.20 & 1.00 & 0.45 & 1.44 \\
\hline${ }^{3}$ GLECEVAG & MET1000 & 100.40 & 0.60 & 1.49 & 100.20 & 1.00 & 0.45 & 2.78 \\
\hline${ }^{4}$ VILDACROSS & VLD 50 & 99.80 & 1.54 & 0.29 & 100.08 & 1.10 & 0.16 & 1.96 \\
\hline${ }^{5}$ NOVELDO & VLD 50 & 99.28 & 1.37 & 1.18 & 99.56 & 0.88 & 1.12 & 2.39 \\
\hline${ }^{6}$ VIGLY & VLD 50 & 100.16 & 1.88 & 0.19 & 99.76 & 1.48 & 0.36 & 1.61 \\
\hline $\begin{array}{l}{ }^{7} \text { GLICLAZIDE } \\
\text { ASIA }\end{array}$ & GLZ 80 & 100.90 & 1.19 & 1.68 & 99.30 & 1.71 & 0.92 & 2.01 \\
\hline${ }^{8}$ CROACTIF-XR & GLZ 30 & 99.30 & 1.11 & 1.42 & 101.5 & 1.87 & 1.76 & 2.98 \\
\hline${ }^{9}$ UNICRON-XR & GLZ 60 & 100.40 & 1.39 & 0.64 & 99.20 & 1.81 & 0.99 & 1.65 \\
\hline${ }^{10}$ GLIPTIN & STG 100 & 99.70 & 0.30 & 2.24 & 100.40 & 0.50 & 1.79 & 2.78 \\
\hline${ }^{11} \mathrm{JANU}$ & STG 50 & 100.80 & 1.39 & 1.28 & 98.8 & 2.02 & 1.34 & 2.04 \\
\hline 12 KATAZONA & PGZ 15 & 98.20 & 1.62 & 2.51 & 99.20 & 1.81 & 0.99 & 1.26 \\
\hline${ }^{13}$ PIOGLIT & PGZ 30 & 100.90 & 1.39 & 1.44 & 99.60 & 1.70 & 0.53 & 1.47 \\
\hline${ }^{14}$ GLU-STAT & GLB 5 & 100.10 & 1.10 & 0.20 & 99.70 & 1.50 & 0.45 & 1.86 \\
\hline${ }^{15}$ GLYNASE & GLB 5 & 98.40 & 1.63 & 2.24 & 100.60 & 1.79 & 0.74 & 1.26 \\
\hline${ }^{16}$ GLIMARYL & GLM 2 & 100.60 & 0.69 & 1.92 & 99.60 & 0.40 & 2.24 & 3.06 \\
\hline${ }^{17}$ AMARAX & GLM 2 & 101.40 & 1.18 & 2.61 & 99.20 & 1.81 & 0.09 & 2.25 \\
\hline \multirow{2}{*}{${ }^{18}$ JANU PLUS } & MET 500 & 100.26 & 0.39 & 1.49 & 99.66 & 0.44 & 1.72 & 1.27 \\
\hline & STG 50 & 100.32 & 1.69 & 0.42 & 99.76 & 1.86 & 0.29 & 1.20 \\
\hline${ }^{19}$ NOVELDO- & MET 500 & 100.11 & 0.59 & 0.42 & 100.42 & 0.95 & 0.98 & 2.65 \\
\hline MET & VLD 50 & 101.20 & 1.98 & 1.34 & 99.60 & 1.30 & 0.69 & 2.37 \\
\hline \multirow{2}{*}{${ }^{20}$ PIOGLIT MET } & MET 500 & 100.20 & 0.91 & 0.49 & 99.97 & 0.84 & 0.08 & 1.17 \\
\hline & PGZ 15 & 99.18 & 0.91 & 2.01 & 100.69 & 1.50 & 1.03 & 2.78 \\
\hline \multirow{2}{*}{${ }^{21}$ GLYFORM } & MET500 & 100.80 & 1.31 & 1.36 & 99.50 & 0.61 & 0.18 & 4.68 \\
\hline & GLB 5 & 100.40 & 0.10 & 0.90 & 100.30 & 1.00 & 0.67 & 1.16 \\
\hline \multirow{2}{*}{${ }^{22}$ BIFECT } & PGZ 30 & 99.45 & 0.82 & 1.49 & 100.42 & 1.41 & 1.52 & 3.03 \\
\hline & GLM 4 & 99.75 & 1.00 & 0.56 & 100.75 & 1.49 & 1.12 & 2.25 \\
\hline
\end{tabular}

Five independent analyses. At 95\% confidence level, t-value is 2.776 and F-value is 6.26. 1, 8, 21 supplied by Citypharma, Syria; 2, 5, 9, 19 supplied by Unipharma, Syria; 3 supplied by Bahri, Syria; 4 supplied by Medico, Syria; 7, 11, 16, 18 supplied by Asia, Syria; 10 supplied by Altramedica, Syria; 12 supplied by Alma, Syria; 13, 20 supplied by Barakat, Syria; 6, 14 supplied by Tamico, Syria; 15 supplied by Julphar. 1, 2, 3, 7, 8, 9, 14, 15 reference method [52]; 12, 13, 16, 17, 21 reference method [53]; 4, 5, 6 reference method [23]; 10, 11 reference method [30]; 18 reference method [54], 19 reference method [55], 20, 22 reference method [56]. 


\section{Conclusion}

In this paper, the proposed high-precision RPHPLC method has been validated. Full results have proven this improved method to be convenient and effective in the determination of all seven active ingredients during the analysis of bulk and pharmaceutical forms. The proposed method requires few chemical reagents and is simple, sensitive and selective. Moreover, low analysis time leads to increased cost-effectiveness. The method can be used in quality control testing in the pharmaceutical industry.

\section{Acknowledgement}

The authors express their thanks to the Department of Chemistry at Damascus University, Faculty of Sciences and City Pharma Laboratories for their assistance during the work.

\section{References}

[1] Inzucchi, S. E.; Bergenstal, R. M.; Buse, J. B., Diabetes Care, 2012, 38, 140-149.

[2] Drug profile for Metformin $\mathrm{HCl}$ available, https://www.drugs.com/pro/metformin.html , 2019.

[3] El Ouaghlidi, A.; Rehring, E.; Holst, J. J.; Juul, J.; Schweizer, A.; Foley, J., J. Clin. Endocrinol. Metab., 2007, 92, 4165-4171.

[4] Mathieu, C.; Degrande, E., Vasc. Health Risk Manage., 2008, 4, 349-1360.

[5] Remington, The Science and Practice of Pharmacy, $20^{\text {th }}$ Edition, Lippincott Williams \& Wilkins, USA, 2000, 1526.

[6] Herman, G. A.; Bergman A.; Liu F., Journal of Clinical Pharmacology, 2006, 46, 876886.

[7] Sweetman, S. C., Martindale: The Complete Drug Reference, $36^{\text {th }}$ Edition, Chicago: Pharmaceutical Press Cop., 2009.

[8] Idries Amjad, M.; Mohammed, E.; Mahmoud, E.; Kamal, E., Sudan J. Med. Sci., 2012, 7, 153-159.

[9] Javaid, A.; Hasan, R.; Zaib, A.; Mansoor, S., Pak. J. Pharm. Sci., 2007, 20, 67-71.

[10] Glimepiride, http://www.drugbank.ca/drugs/DB00222 .

[11] Nissen, S. E.; Nicholls, S. J.; Wolski, K., Jama, 2008, 299, 1561-1573.

[12] Davis, S. N., in: Goodman \& Gilman's The Pharmacological Basis of Therapeutics, L. L. Brunton, J. S. Lazo and K. L. Parker, Eds., 2005, 1636.

[13] Mubeen, G.; Noor, K., J. Pharm., 2009, 71, $100-102$.
[14] Mubeen, G.; Noor, K., Chem. Tech., 2010, $2,1330-1331$.

[15] Monica, A.; Valtierra-Alvarado, M.; Pamela S. G.; María R. G. P.; José J. N. S. G., J. Sci. Res. Publ., 2015, 5, 2250-3153.

[16] Dhaneshwar, S.; Havele, S., J. Nanomed. Nanotechnol., 2010, 1, 1-3.

[17] Saikiran, G., J. Pharm. Pharm. Sci., 2014, 1149-1159.,

[18] Attia, A. K.; Salem, W. M.; Mohamed, M. A., Acta Chim. Slov., 2015, 62, 588-594.

[19] Hadi, M.; Poorgholi, H.; Mostaanzadeh, H., Afr. J. Chem., 2016, 69, 132-139.

[20] Blanco Jerez, L. M.; García-Pérez, U. M.; Zambrano-Robledo, P.; Hernández-Moreira, J., Int. J. Electrochem., 2014, 9, 46434652.

[21] Naveed, S.; Rehman, H.; Qamar, F.; Zainab, S., Int. J. Pharm. Sci. Res., 2014, 5, 714-717.

[22] Younes, O. M.; Al-Zehouri, J.; Abboud, H., Int. J. Pharm. Sci. Rev. Res., 2014, 29, $33-$ 36.

[23] Khatun, R.; Mirazunnabi, M. D., Int. J. Pharm. Life Sci., 2013, 2, 90-98.

[24] Sultana, R.; Bachar, S. C.; Rahman, F., Int. J. Pharm. Life Sci., 2013, 4, 2530-2534.

[25] Enany, N. E., Farmaco, 2004, 59, 63-69.

[26] Enany, N. E., J. AOAC Int., 2003, 86, 219214.

[27] Retnaningtyas, Y.; Wulandari, L.; Erliana, F., Int. C. Pharm. J., 2012, 1, 332-335. 
[28] Kumar, R.; Patnaik, A. K.; Raul, S. K.; Rao, N. N., J. Appl. Pharm. Sci., 2013, 3, 059062.

[29] Sekaran, B. C.; Rani, P. A., Int. J. Pharm. Pharm. Sci., 2010, 2, 138-142.

[30] Dhiraj, K.; Reddy, L. R.; Kaur, P.P.; Kumar, M. N. N., J. Pharm. Res., 2012, 5, 4421-4424.

[31] Sarowar, G. S.; Deshpande, P.B.; Gandhi, Y. R.; Bhatt, J. J., J. Pharm. Med. Res., 2016, 3, 213-218.

[32] Ahmed, R. M.; Hadad, G. M.; El-Gendy, A. E.; Ibrahim, A., Anal. Chem. Lett., 2018, 8, 813-828.,

[33] El-Kosasy, A. M.; Abd El Aziz, L ; Trabik, Y. A., J. Appl. Pharm. Sci., 2012, 2, 51-56.

[34] Alarfaj, N.; Abdel-Razeq, S. A.; Al-Hoshan, A. A., Asian J. Chem., 2011, 23, 41044108 .

[35] Okdeh, M.; Sakur, A. A.; Alfares, B., Int. J. Pharm. Pharm. Sci., 2014, 6, 43-47.

[36] Ashour, S.; Sakur, A. A.; Kudemati, M., Can. Chem. Trans., 2015, 3, 1-11.

[37] Ravikanth, C.; Kumar, A. A.; Kiran, V. U.; Prashanth, S.; Madhu, B.; Reddy Y. N., Inter. J. Pharm. Sci. Drug Res., 2011, 3, $38-41$.

[38] Mandil, H.; Sakur, A. A.; Alulu, S., Int. J. Pharm. Pharm. Sci., 2013, 5, 86-93.

[39] Al-Arfaj, N. A.; Al-Abdulkareem, E. A.; Aly, F. A., 2008, 4, 310-318.

[40] Parameswararao, K.; Satynarayana, M. V.; Raju, T. N.; Ramana, G. V., Sch. Res. Library, 2012, 4, 2449-2452.

[41] Punugoti, R. A.; Jupally, V. R., Inter. J. Pharm. Bio. Chem. Sci., 2013, 2, 52-56.

[42] Hag, N.; Alanazi, F. K.; Alsarra, I. A.; Shakee, F., Iran. J. Pharm. Res., 2014, 13, 863-872.
[43] Sudha, T.; Krishna, V.; Kumar, R., Turk. J. Pharm. Sci., 2014, 11, 307-316.,

[44] Radi, A. E.; Eissa, S., J. Incl. Phenom. Macrocycl. Chem., 2010, 68, 417-421.

[45] Karad, M. D.; Barhate, V. D., Inter. J. Drug Dev. Res., 2016, 6, 7464-7467.

[46] Ramadan, A. A.; Mandil, H.; Zeino, S., Int. J. Pharm. Pharm. Sci., 2016, 8, 216-221.

[47] Ibragimova, M. M.; Ikramov, L. T., Adli Tip. Bülteni., 2015, 20, 71-75.

[48] Samala, S.; Tatipamula, S. R.; Veeresham, C., Amer. J. Anal. Chem., 2011, 2, 152-157.

[49] FDA - Guidance for Industry, Validation of Analytical Procedures: Definition and Terminology Final Guidance, FDA, Silver Spring, MD, USA, 2010.

[50] The International Council for Harmonization of Technical Requirements for Pharmaceuticals for Human Use (ICH), Validation of Analytical Procedures: Text and Methodology Q2(R1), ICH, Geneva, Switzerland, 2005.

[51] Forootan, A.; Sjoback, R.; Orkman, J. B.; Ogreen, B. S.; Linz, L.; Kubista, M., Biomolec. Det. Quant., 2017, 3, 1-6.

[52] British Pharmacopoeia, Her Majesty Stationery Officer, London, UK, 2013.

[53] USP, 38-NF 33, 12601 Twinbrook Parkway, Rockville, MD 20852.

[54] Jeyabalan, G.; Nyola, N., J. Pharm. Ed. Res., 2012, 3, 24-28.

[55] Baokar, S. B.; Mulgund, S. V.; Ranpis, N. S., Res. J. Pharm. Dos. Forms Tech., 2013 , 5, 95-98.

[56] Nirupa, G.; TripathI, U. M., J. Chem., 2013, $2,1-8$. 